\title{
BMJ Open Incidence and prevalence of type 2 diabetes mellitus with HIV infection in Africa: a systematic review and meta- analysis
}

\author{
A Prioreschi, ${ }^{1}$ R J Munthali, ${ }^{1} \mathrm{~L}$ Soepnel, ${ }^{1,2} \mathrm{~J}$ A Goldstein, ${ }^{3} \mathrm{~L}$ K Micklesfield, ${ }^{1}$ \\ D M Aronoff, ${ }^{4} \mathrm{~S}$ A Norris ${ }^{1}$
}

To cite: Prioreschi $A$, Munthali RJ, Soepnel L, et al. Incidence and prevalence of type 2 diabetes mellitus with HIV infection in Africa: a systematic review and metaanalysis. BMJ Open 2017;7: e013953. doi:10.1136/ bmjopen-2016-013953

- Prepublication history and additional material is available. To view please visit the journal (http://dx.doi.org/ 10.1136/bmjopen-2016013953)

Received 19 August 2016 Revised 1 December 2016 Accepted 6 December 2016

CrossMark

For numbered affiliations see end of article.

\section{Correspondence to} Dr Alessandra Prioreschi; Alessandra.prioreschi@wits. ac.za

\section{ABSTRACT}

Objectives: This systematic review aims to investigate the incidence and prevalence of type 2 diabetes mellitus (T2DM) in patients with HIV infection in African populations.

Setting: Only studies reporting data from Africa were included.

Participants: A systematic search was conducted using four databases for articles referring to HIV infection and antiretroviral therapy, and T2DM in Africa. Articles were excluded if they reported data on children, animals or type 1 diabetes exclusively.

Main outcome measures: Incidence of T2DM and prevalence of T2DM. Risk ratios were generated for pooled data using random effects models. Bias was assessed using an adapted Cochrane Collaboration bias assessment tool.

Results: Of 1056 references that were screened, only 20 were selected for inclusion. Seven reported the incidence of T2DM in patients with HIV infection, eight reported the prevalence of T2DM in HIV-infected versus uninfected individuals and five reported prevalence of T2DM in HIV-treated versus untreated patients. Incidence rates ranged from 4 to 59 per 1000 person years. Meta-analysis showed no significant differences between T2DM prevalence in HIV-infected individuals versus uninfected individuals (risk ratio $(R R)=1.61$, $95 \% \mathrm{Cl} 0.62$ to $4.21, \mathrm{p}=0.33$ ), or between HIV-treated patients versus untreated patients $(\mathrm{RR}=1.38,95 \% \mathrm{Cl}$ 0.66 to $2.87, p=0.39$ ), and heterogeneity was high in both meta-analyses $\left(\mathrm{I}^{2}=87 \%\right.$ and $52 \%$, respectively). Conclusions: Meta-analysis showed no association between T2DM prevalence and HIV infection or antiretroviral therapy; however, these results are limited by the high heterogeneity of the included studies and moderate-to-high risk of bias, as well as, the small number of studies included. There is a need for welldesigned prospective longitudinal studies with larger population sizes to better assess incidence and prevalence of T2DM in African patients with HIV. Furthermore, screening for T2DM using gold standard methods in this population is necessary.

Trial registration number: PROSPER042016038689.

\section{Strengths and limitations of this study}

- This is the first systematic review of the literature examining associations between HIV infection and treatment with type 2 diabetes mellitus (T2DM) incidence and prevalence in Africa.

- The stringent inclusion criteria used is a strength of this systematic review.

- Differences in methods of T2DM diagnosis across studies is a limitation.

- Heterogeneity and moderate-to-high risk of bias across studies is a limitation.

- The small number of studies meeting the inclusion criteria is a limitation.

\section{BACKGROUND}

The introduction of combination antiretroviral therapies (cARTs) in the treatment of HIV infection has resulted in significant extension of the predicted lifespan of patients with HIV infection. ${ }^{1}$ Consequently, patients with HIV are potentially at a greater risk of developing non-communicable diseases than due to the ageing process alone; as the disease itself, ${ }^{2}$ and treatments used to combat HIV, are associated with metabolic complications. ${ }^{3}$

Type 2 diabetes mellitus (T2DM) is one such disease that is becoming increasingly common, specifically in Africa due to rapidly transitioning lifestyles. An estimated 12.1 million people were living with T2DM in Africa in $2010^{4}$ and it is predicted that this will increase to 23.9 million by 2030 . Besides associations with age, obesity, sex and race, ${ }^{5}$ recent studies have associated T2DM with HIV infection, and with cART. $^{1}{ }^{3}{ }^{5}$ The mechanisms underlying these associations are not fully elucidated, but may reflect chronic systemic inflammation in response to HIV infection despite treatment, ${ }^{6} 7$ antiretroviral drug-induced mitochondrial dysfunction, 
lipodystrophy and comorbidities. ${ }^{5}$ Conversely, some studies have shown a decreased incidence of T2DM in HIV-infected individuals compared with uninfected individuals. $^{8}{ }^{9}$ T2DM is associated with increased morbidity and mortality, an estimated 1.5 million deaths were attributed directly to T2DM in 2012, ${ }^{10}$ and the implications of HIV infection and treatment on the incidence of T2DM is therefore important to explore. The aim of this systematic review is to investigate the incidence of T2DM in patients with HIV infection in Africa, as well as, the prevalence of T2DM in patients with HIV infection treated with cART in comparison with non-infected and nontreated individuals.

\section{METHODS}

The systematic review focused on the associations between HIV infection, antiretroviral therapy and T2DM. This review was registered in the PROSPERO registry for systematic reviews (registration number 42016038689), ${ }^{11}$ and was conducted in accordance with the PRISMA guidelines. ${ }^{12}$

\section{Search strategy}

The search for this systematic review was conducted in May 2016 and included terms in the determinants of HIV infection and antiretroviral therapy, the domain of Africa and the outcome of T2DM. Restrictions included age ( $>13$ years), date of publication (after 1 January 2008 due to the presence of an existing review examining prevalence of T2DM in HIV conducted in $2008^{13}$ ). The title and abstracts of articles in PubMed, Scopus, the Cochrane library and Embase were searched; and a sample of the Embase search strategy is available online as a supplementary file. Keywords used included: 'HIV', 'diabetes', 'Africa' and 'antiretroviral therapy'.

\section{Study selection}

All observational studies (cohort, case-control and cross sectional) that assessed the relationship between HIV seropositivity with or without cART therapy, and T2DM in Africa were included. Animal studies, biomolecular studies, studies not written in English or French, case reports and secondary analyses were excluded. Studies reporting outcomes in children or pregnant women, or reporting type 1 diabetes outcomes only, or not reporting T2DM incidence or prevalence (but hyperglycaemia or impaired glucose tolerance for example) were also excluded. Studies that did not report prevalence of T2DM in HIV-infected participants compared with HIV-uninfected participants; or prevalence of T2DM between cART exposure compared with untreated patients with HIV; or incidence of T2DM in patients with HIV infection were excluded. Authors of individual studies defined the criteria for T2DM diagnoses, and variant criteria were included provided diagnosis was made using a recognised score for a fasted blood glucose, or an oral glucose tolerance test (OGTT), or glycated haemoglobin (HbAlc) values. ${ }^{14}$

\section{Screening and data extraction}

Two independent reviewers (AP, RJM) independently screened all articles retrieved by the search strategy by title and abstract for eligibility according to inclusion and exclusion criteria. Any discrepancies between the
Figure 1 Flow diagram of article selection process and reasons for inclusion and exclusion.

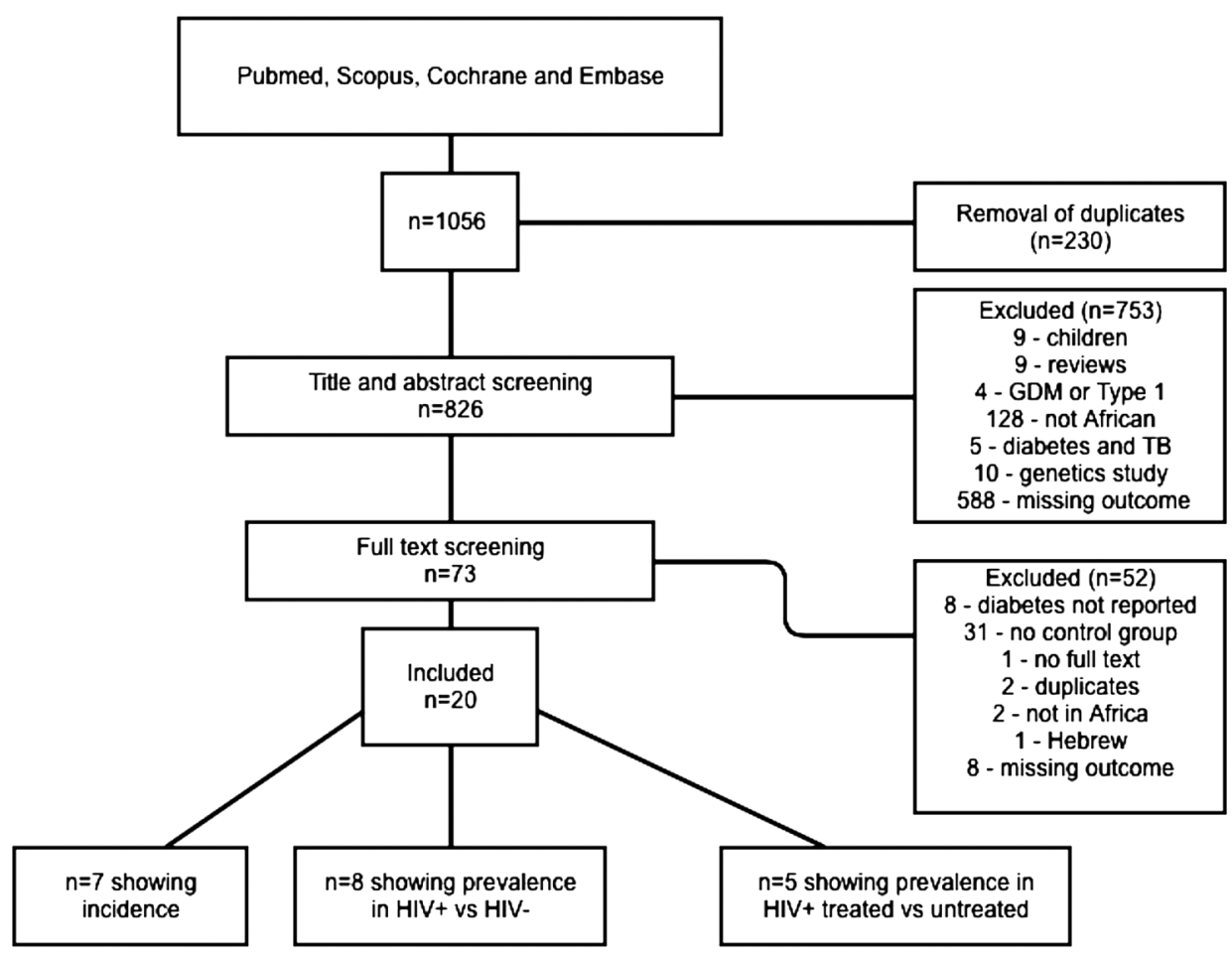


Table 1 Overview of diagnostic criteria used in the included studies

Criteria
used Definitions

WHO Fasting plasma glucose $\geq 7.0 \mathrm{mmol} / \mathrm{L}(126 \mathrm{mg} / \mathrm{dL})$ or $2-\mathrm{h}$ plasma glucose $\geq 11.1 \mathrm{mmol} / \mathrm{L}(200 \mathrm{mg} / \mathrm{dL})$.

ADA Fasting plasma glucose $\geq 126 \mathrm{mg} / \mathrm{dL}(7.0 \mathrm{mmol} / \mathrm{L})$ or 2-hour plasma glucose $\geq 200 \mathrm{mg} / \mathrm{dL}(11.1 \mathrm{mmol} / \mathrm{L})$ during OGTT $(75 \mathrm{~g})$ or A1C $\geq 6.5 \%(48 \mathrm{mmol} / \mathrm{mol})$ or Random plasma glucose $\geq 200 \mathrm{mg} / \mathrm{dL}(11.1 \mathrm{mmol} / \mathrm{L})$

NCEP Fasting plasma glucose $\geq 5.6 \mathrm{mmol} / \mathrm{L}$

cut-offs

IDF $\quad F P G \geq 100 \mathrm{mg} / \mathrm{dl}(5.6 \mathrm{mmol} / \mathrm{L})$

A1C, glycated haemoglobin; ADA, American diabetes association; IDF, International Diabetes Federation; FPG, fasting plasma glucose; NCEP, National Cholesterol Education Programme; OGTT, oral glucose tolerance test.

two reviewers were discussed and consensus was reached. The full text was accessed if necessary for further clarification. Full texts of eligible articles were then retrieved and divided among all reviewers. If no full text was available, one attempt was made to contact the author. Each full text was assessed for eligibility by one reviewer, and a second reviewer was available for consultation. Data extraction was then performed using a standardised data extraction form. One reviewer (AP) reassessed data extraction for all eligible full texts. Data of interest was study design, study setting and country, population, age, body mass index (BMI), number of patients included in each group, control population, cART treatment at the time of inclusion, duration of cART treatment, method of T2DM diagnosis, incidence of known risk factors for T2DM such as obesity, treatment provided for T2DM, incidence of T2DM in the control group and group with HIV and/or antiretroviral therapy, when applicable OR/risk ratio (RR) and follow-up duration. In cases of incomplete data, one attempt was made to contact the corresponding author by email and if no response was received the paper was excluded.

\section{Data synthesis}

Three separate analyses were performed for articles that examined incidence of T2DM; prevalence of T2DM in HIV-infected versus uninfected participants; and prevalence of T2DM in HIV-infected and treated versus untreated participants. Meta-analysis was conducted for articles with sufficiently homogenous outcome measures and study designs. The principle summary measure used was RR, and in cases of substantial heterogeneity $\left(\mathrm{I}^{2}>50 \%\right)$, according to the Cochrane handbook, ${ }^{15}$ a binary random effects model (using the DerSimonian-Laird method) was applied. Analyses were conducted using OpenMetaAnalyst. A priori subgroup analyses based on geographical localisation, age, antiretroviral therapy (ART) medication/treatment strategy and duration, severity of HIV and method of T2DM diagnosis were not possible due to insignificant subcategorisation of data and insufficient number of included studies. ${ }^{15}$

\section{Risk of bias assessment}

Studies were assessed for risk of bias using the Evidence Partner's risk of bias tool for cohort studies ${ }^{16}$ as 'low

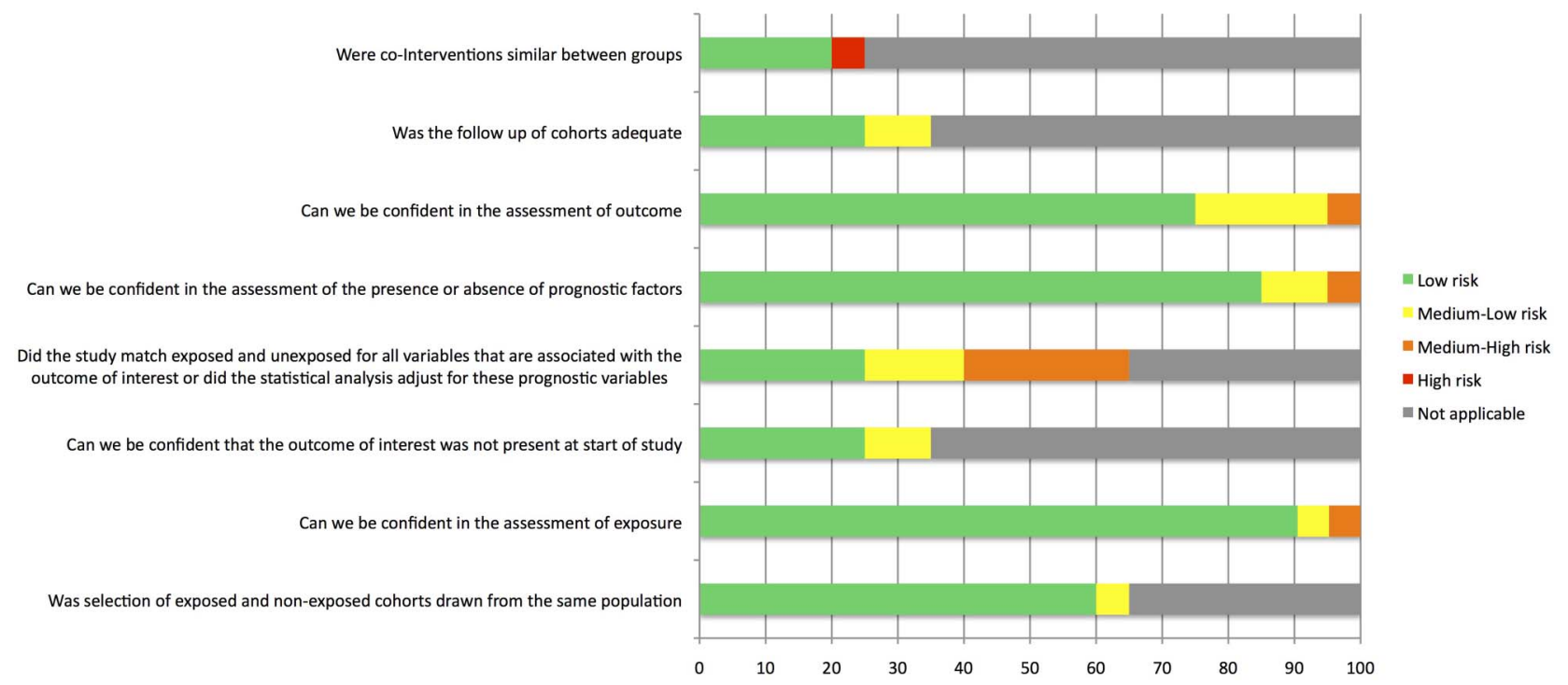

Figure 2 Risk of bias assessment for studies included in the analysis. 


\begin{tabular}{|c|c|c|c|c|c|c|c|c|c|c|c|c|c|}
\hline Author, year & Setting & Population & Case & Control & ART & $\begin{array}{l}\text { Follow-up } \\
\text { mean/ } \\
\text { median }\end{array}$ & $\begin{array}{l}\text { Diagnosis of } \\
\text { T2DM }\end{array}$ & $\begin{array}{l}\text { Prevalence at } \\
\text { baseline } n(\%)\end{array}$ & $\begin{array}{l}\text { Prevalence } \\
\text { at follow-up } \\
\mathrm{n}(\%)\end{array}$ & $\begin{array}{l}\text { Cumulative } \\
\text { incidence }\end{array}$ & $\begin{array}{l}\text { Incidence } \\
\text { proportion }\end{array}$ & $\begin{array}{l}\text { Incidence } \\
\text { rate (per } \\
1000 \\
\text { person } \\
\text { years) }\end{array}$ & p Value \\
\hline $\begin{array}{l}\text { Abrahams, } \\
2015\end{array}$ & $\begin{array}{l}\text { South } \\
\text { Africa }\end{array}$ & $\begin{array}{l}103 \text { women } \\
\text { Mean } \\
\text { age }=33.5 \\
\text { Mean } \\
\text { BMl=27.9 }\end{array}$ & NA & NA & $\begin{array}{l}\text { Stavudine/ } \\
\text { lamivudine }\end{array}$ & $\begin{array}{l}5.5 \text { years } \\
\mathrm{n}=94\end{array}$ & ADA criteria & $1(1.0)$ & $7(7.5)$ & $6.5 \%$ & $5.83 \%$ & 11 & 0.07 \\
\hline George, 2009 & $\begin{array}{l}\text { South } \\
\text { Africa }\end{array}$ & $\begin{array}{l}42 \text { black } \\
\text { participants, } \\
65 \% \text { women } \\
\text { Mean } \\
\text { age }=34.4 \\
\text { Mean } \\
\text { BMl=22.7 }\end{array}$ & NA & NA & $\begin{array}{l}\text { Stavudine/ } \\
\text { zidovudine }\end{array}$ & $\begin{array}{l}2 \text { years } \\
n=42\end{array}$ & NCEP cut-off & $1(2.4)$ & $1(2.5)$ & $0.1 \%$ & $0.001 \%$ & 5 & $>0.05$ \\
\hline $\begin{array}{l}\text { Karamchand, } \\
2016\end{array}$ & $\begin{array}{l}\text { South } \\
\text { Africa }\end{array}$ & $\begin{array}{l}56298 \\
\text { participants, } \\
64 \% \text { women } \\
\text { Mean } \\
\text { age=38.14 } \\
\text { Mean } \\
\text { BMl=25.95 }\end{array}$ & NA & NA & $\begin{array}{l}\text { First line } \\
\text { NNRTI } \\
\text { regimen } \\
\text { containing } \\
\text { efavirenz or } \\
\text { nevirapine }\end{array}$ & $\begin{array}{l}1.56 \text { years } \\
n=56298\end{array}$ & $\begin{array}{l}\text { Prescription } \\
\text { of } \\
\text { anti-diabetic } \\
\text { medication }\end{array}$ & $0(0)$ & $1500(2.66)$ & $2.66 \%$ & $2.66 \%$ & 13 & $\begin{array}{l}\text { Not } \\
\text { reported }\end{array}$ \\
\hline Magula, 2014 & $\begin{array}{l}\text { South } \\
\text { Africa }\end{array}$ & $\begin{array}{l}238 \\
\text { participants }\end{array}$ & $\begin{array}{l}\mathrm{n}=150 \\
\text { treated }\end{array}$ & $\begin{array}{l}\mathrm{n}=88 \\
\text { uninfected }\end{array}$ & $\begin{array}{l}\text { Initiated- } \\
\text { tenofovir, } \\
\text { lamivu- dine, } \\
\text { efavirenz/ } \\
\text { nevirapine }\end{array}$ & $\begin{array}{l}2 \text { years } \\
n=150\end{array}$ & WHO criteria & $0(0)$ & 13 (8.66) & $8.66 \%$ & $8.66 \%$ & 59 & $\begin{array}{l}\text { Not } \\
\text { reported }\end{array}$ \\
\hline Ndona, 2012 & DRC & $\begin{array}{l}102 \\
\text { participants, } \\
51 \% \text { women, } \\
\text { Mean } \\
\text { age=43.4 } \\
\text { Mean } \\
\text { BMI=23.1 }\end{array}$ & $\begin{array}{l}\mathrm{n}=49 \\
\mathrm{HIV+} \\
\text { treated }\end{array}$ & $\begin{array}{l}\mathrm{n}=53 \mathrm{HIV} \\
+ \\
\text { untreated }\end{array}$ & $\begin{array}{l}\text { Stavudine }+ \\
\text { lamivudine, } \\
\text { zidovudine }+ \\
\text { lamivudine }+ \\
\text { nevirapine, or } \\
\text { efavirenz }\end{array}$ & $\begin{array}{l}4 \text { years } \\
n=102\end{array}$ & WHO criteria & Not stated & $5(4.9)$ & $4.9 \%$ & $4.9 \%$ & 10 & 0.06 \\
\hline Sagna, 2013 & $\begin{array}{l}\text { Burkino } \\
\text { Faso }\end{array}$ & $\begin{array}{l}144 \\
\text { participants, } \\
\text { Mean age=37 }\end{array}$ & NA & NA & $\begin{array}{l}\text { Not stated } \\
\text { (first-line } \\
\text { therapy) }\end{array}$ & $\begin{array}{l}3 \text { years } \\
n=128\end{array}$ & Not stated & Not stated & $3(2.3)$ & $2.3 \%$ & $2.1 \%$ & 7 & $\begin{array}{l}\text { Not } \\
\text { reported }\end{array}$ \\
\hline Zannou, 2009 & Benin & $\begin{array}{l}79 \\
\text { participants, } \\
59.5 \% \\
\text { women } \\
\text { Mean age=38 } \\
\text { Mean } \\
\text { BMl=19.2 }\end{array}$ & NA & NA & $\begin{array}{l}\text { All started } \\
\text { combination } \\
\text { therapy. } \\
\text { Lamivudine + } \\
\text { stavudine } \\
\text { +efavirenz }\end{array}$ & $\begin{array}{l}2 \text { years } \\
n=61\end{array}$ & WHO criteria & $0(0)$ & $6(7.6)$ & $7.6 \%$ & $7.6 \%$ & 4 & $\begin{array}{l}\text { Not } \\
\text { reported }\end{array}$ \\
\hline
\end{tabular}

ADA, American Diabetes Association; ART, antiretroviral therapy; BMI, body mass index; DRC, Democratic Republic of Congo; NCEP, National Cholesterol Education Programme; NNRTI, non-nucleotide reverse transcriptase inhibitors; T2DM, type 2 diabetes mellitus. 


\section{Incidence Rates (per 1000 person years)}

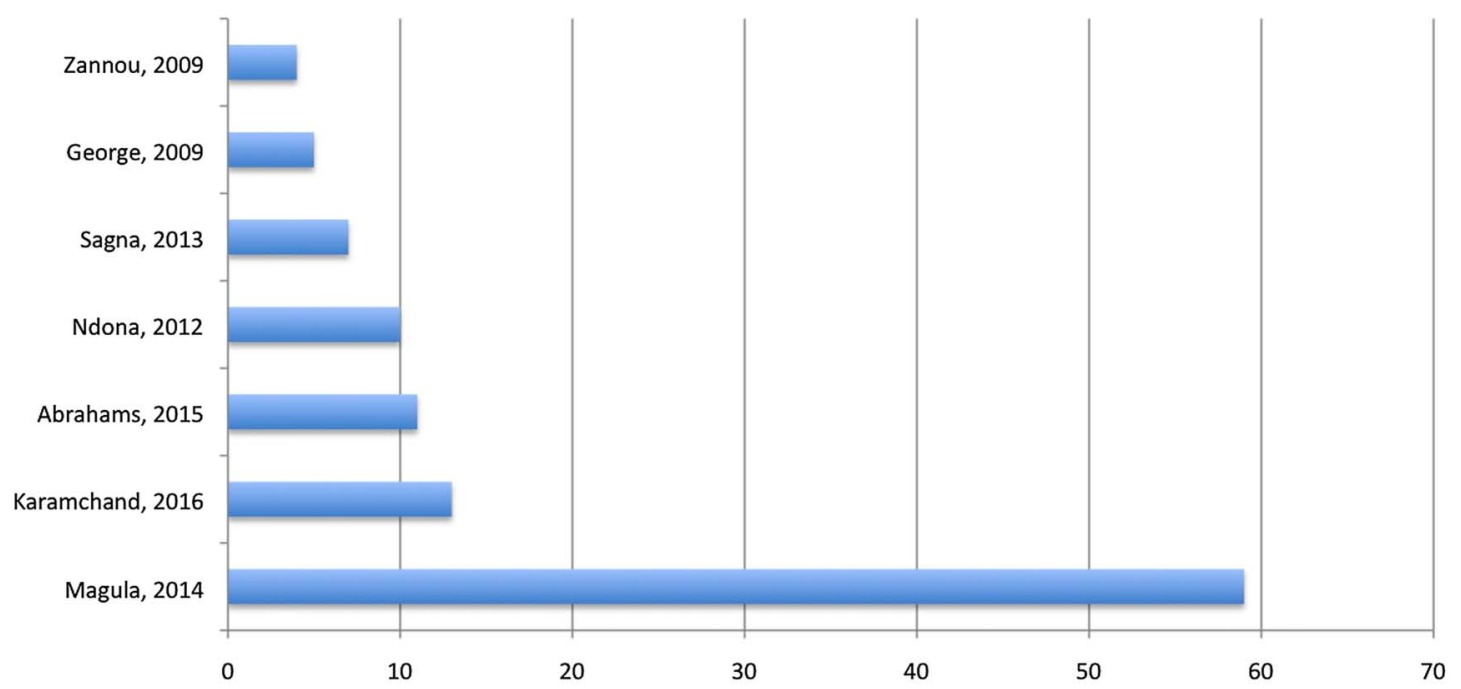

Figure 3 Incidence rates of T2DM in HIV-infected and treated participants in Africa. T2DM, type 2 diabetes mellitus.

risk', 'medium-low risk', 'medium-high risk', 'high risk' or 'not applicable' for the categories of: similarity of intervention, adequacy of follow-up, assessment of outcome, assessment of prognostic factors, matching relevant variables between case and control, presence of outcome of interest at start of the study, assessment of exposure and selection of populations. This tool is available as an online supplementary file.

\section{RESULTS}

The search provided 1056 results. After screening, 20 articles met the eligibility criteria ${ }^{17-36}$ and were included in the analysis (figure 1). Of these, seven ${ }^{17-23}$ articles reported incidence of T2DM in HIV-infected participants, eight ${ }^{24-31}$ reported prevalence of T2DM in HIV-infected participants compared with uninfected controls and five ${ }^{32-36}$ reported prevalence of T2DM in HIV-infected participants on treatment compared with untreated controls. In included studies, T2DM was diagnosed if participants were being treated for T2DM, or by OGTT. As summarised in table 1, four main criteria were used: WHO, American Diabetes Association (ADA), International Diabetes Federation (IDF) and National Cholesterol Education Programme (NCEP) criteria.

\section{Risk of bias}

A summary of the risk of bias assessment is presented in figure 2. All included studies were observational, and 15 (71\%) were case-control studies. In $5 \%$ of studies, there was a high risk of bias due to HIV treatment not being stated. In $25 \%$ of studies, there was a medium-high risk of bias due to confounding variables. Four (20\%) of the studies had medium-low risk of bias due to T2DM diagnosis criteria. Three $(14 \%)$ included studies were published conference proceedings.
Incidence of T2DM in HIV-infected participants

Seven studies reported T2DM incidence in HIV-infected participants ( $n=57006$; table 2). One of the included studies compared incidence in treated versus untreated participants, $^{21}$ and another compared incidence in infected versus uninfected participants. ${ }^{20}$ The rest of the studies assessed incidence in HIV-infected and treated participants with no control group. Most participants were on cART, except for participants in the Sagna et $a l^{22}$ study who were on first-line therapy, which was not clearly specified. Mean age of participants ranged from 33.5 years $^{17}$ to 38 years $^{19} 23$ (age was not stated by Magula et $a l^{20}$ ). Mean BMI ranged from $19.2 \mathrm{~kg} / \mathrm{m} 2^{23}$ to $27.9 \mathrm{~kg} / \mathrm{m} 2,{ }^{17}$ and was not stated in one of the studies. $^{20}$ Mean duration of follow-up ranged from 1.56 years ${ }^{19}$ to 5.5 years, ${ }^{17}$ and the total number of participants followed up to completion was $n=56875$. The majority of participants were women in all studies where sex was stated. Incidence of T2DM was reported as absolute incidence, cumulative incidence, incidence proportion and incidence rate per 1000 person years. Incidence rates ranged from $4^{23}$ to $59,{ }^{20}$ figure 3 . The combined incidence rate for all the included studies over 89640 person years of follow-up was 17.4.

\section{Prevalence of T2DM in HIV-infected compared with uninfected participants}

Table 3 shows the data for eight studies included in a meta-analysis comparing HIV-infected $(n=1715)$ with uninfected participants $(n=2853)$. The majority of included participants were women, except for the study conducted by Brand et $a l,{ }^{27}$ who only included males, and by Becker et $a l,{ }^{26}$ where the majority of participants were male. In four of the included studies, infected participants were not on treatment ${ }^{26272931}$ and in a further two, ${ }^{24} 25$ treatment was not stated. The remaining two 
Table 3 Prevalence data: HIV infected (treated and untreated) versus non-infected

\begin{tabular}{|c|c|c|c|c|c|c|c|c|c|}
\hline $\begin{array}{l}\text { Author, } \\
\text { year }\end{array}$ & Setting & Population & $\begin{array}{l}\text { Case } \\
\text { HIV+ }\end{array}$ & $\begin{array}{l}\text { Control } \\
\text { HIV }\end{array}$ & ART & Diagnosis & $\begin{array}{l}\text { Prevalence } \\
\text { case } \%\end{array}$ & $\begin{array}{l}\text { Prevalence } \\
\text { control \% }\end{array}$ & p Value \\
\hline $\begin{array}{l}\text { Amusa, } \\
2015\end{array}$ & Nigeria & 200 adults & $\begin{array}{l}\mathrm{n}=150,62.6 \% \\
\text { women } \\
\text { Mean age }=40.6\end{array}$ & $\begin{array}{l}n=50,60 \% \\
\text { women } \\
\text { Mean } \\
\text { age }=40.2\end{array}$ & Not stated & $\begin{array}{l}\text { FPG, criteria not } \\
\text { stated }\end{array}$ & 28.0 & 4.0 & 0.01 \\
\hline $\begin{array}{l}\text { Anastos, } \\
2010\end{array}$ & Rwanda & 824 women & $\begin{array}{l}\mathrm{n}=606 \\
\text { Mean age }=42.4 \\
\text { Mean } \mathrm{BMI}=21.1\end{array}$ & $\begin{array}{l}\mathrm{n}=218 \\
\text { Mean } \\
\text { age }=34.7 \\
\text { Mean } \\
\mathrm{BMI}=20.6\end{array}$ & Not stated & $\begin{array}{l}\text { Self-report or WHO } \\
\text { criteria }\end{array}$ & 0.5 & 0.5 & 0.98 \\
\hline $\begin{array}{l}\text { Becker, } \\
2010\end{array}$ & $\begin{array}{l}\text { South } \\
\text { Africa }\end{array}$ & 60 adults & $\begin{array}{l}\mathrm{n}=30,33 \% \\
\text { women } \\
\text { Mean age }=43 \\
\text { Mean } \mathrm{BMI}=25\end{array}$ & $\begin{array}{l}\mathrm{n}=30,40 \% \\
\text { women } \\
\text { Mean } \\
\text { age }=54 \\
\text { Mean } \\
\text { BMl=28 }\end{array}$ & Not on treatment & $\begin{array}{l}\text { Prescription of } \\
\text { anti-diabetic } \\
\text { medication or } \\
\text { diagnosis on } \\
\text { admission }\end{array}$ & 3.0 & 23.0 & 0.05 \\
\hline $\begin{array}{l}\text { Brand, } \\
2014\end{array}$ & $\begin{array}{l}\text { South } \\
\text { Africa }\end{array}$ & $\begin{array}{l}20 \text { black males } \\
\text { requiring } \\
\text { amputation }\end{array}$ & $\begin{array}{l}\mathrm{n}=10 \\
\text { Mean age }=47 \\
\text { Mean } \mathrm{BMI}=22.4\end{array}$ & $\begin{array}{l}\mathrm{n}=10 \\
\text { Mean } \\
\text { age }=62 \\
\text { Mean } \\
\mathrm{BMI}=25.3\end{array}$ & Not on treatment & $\begin{array}{l}\text { WHO criteria or } \\
\text { prescription of } \\
\text { anti-diabetic } \\
\text { medication }\end{array}$ & 50.0 & 0.0 & $<0.05$ \\
\hline $\begin{array}{l}\text { Edwards, } \\
2015\end{array}$ & Kenya & 2206 adults & $\begin{array}{l}n=210,69 \% \\
\text { women } \\
\text { Mean age }=43\end{array}$ & $\begin{array}{l}\mathrm{n}=1996 \\
71 \% \\
\text { women } \\
\text { Mean } \\
\text { age }=49\end{array}$ & $\begin{array}{l}\text { First-line ART used tenofovir/ } \\
\text { lamivudine/efavirenz; second line } \\
\text { lopinavir/ritonavir instead of } \\
\text { efavirenz }\end{array}$ & WHO criteria & 4.8 & 15.0 & $<0.01$ \\
\hline $\begin{array}{l}\text { Fourie, } \\
2010\end{array}$ & $\begin{array}{l}\text { South } \\
\text { Africa }\end{array}$ & 600 adults & $\begin{array}{l}\mathrm{n}=300,61 \% \\
\text { women } \\
\text { Mean age }=44 \\
\text { Mean } \mathrm{BMI}=22.9\end{array}$ & $\begin{array}{l}\mathrm{n}=300, \\
61 \% \\
\text { women } \\
\text { Mean } \\
\text { age }=44 \\
\text { Mean } \\
\text { BMl=22.8 }\end{array}$ & Not on treatment & IDF criteria & 36.6 & 43.7 & 0.64 \\
\hline $\begin{array}{l}\text { Maganga, } \\
2015\end{array}$ & Tanzania & 454 adults & $\begin{array}{l}\mathrm{n}=301,67.8 \% \\
\text { women } \\
\text { Mean age }=37 \\
\text { (untreated) and } \\
40 \text { (treated) } \\
\text { Mean BMI=22.0 } \\
\text { (untreated) and } \\
23.7 \text { (treated) }\end{array}$ & $\begin{array}{l}\mathrm{n}=153, \\
61,4 \% \\
\text { women } \\
\text { Mean } \\
\text { age=38 } \\
\text { Mean } \\
\text { BMl=23.8 }\end{array}$ & $\begin{array}{l}\mathrm{n}=151 \text { not on treatment } \\
\mathrm{n}=150 \text { on treatment- }-21 \% \text { on } \\
\text { protease inhibitors (lopinavir and } \\
\text { ritonavir); rest on other ART: } \\
\text { nevirapine, efavirenz, tenofovir, } \\
\text { stavudine, zidovudine }\end{array}$ & WHO criteria & 9.3 & 5.2 & $\begin{array}{l}0.04 \text { (untreated vs control) } \\
\text { and } 0.001 \text { (treated vs } \\
\text { control) }\end{array}$ \\
\hline $\begin{array}{l}\text { Ngatchou, } \\
2013\end{array}$ & Cameroon & 204 adults & $\begin{array}{l}\mathrm{n}=108,74 \% \\
\text { women } \\
\text { Mean age=39 } \\
\text { Mean } \mathrm{BMI}=25.1\end{array}$ & $\begin{array}{l}\mathrm{n}=96,72 \% \\
\text { women } \\
\text { Mean } \\
\text { age }=41 \\
\text { Mean } \\
\text { BMl=28.1 }\end{array}$ & Not on treatment & WHO criteria & 26.0 & 1.0 & 0.01 \\
\hline
\end{tabular}




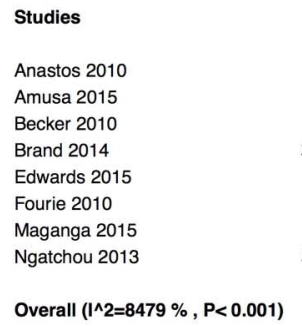

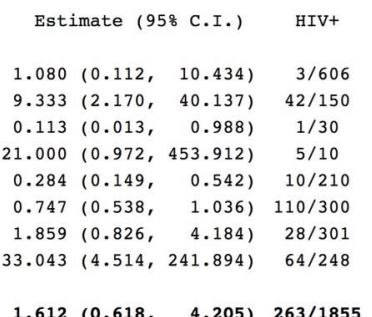

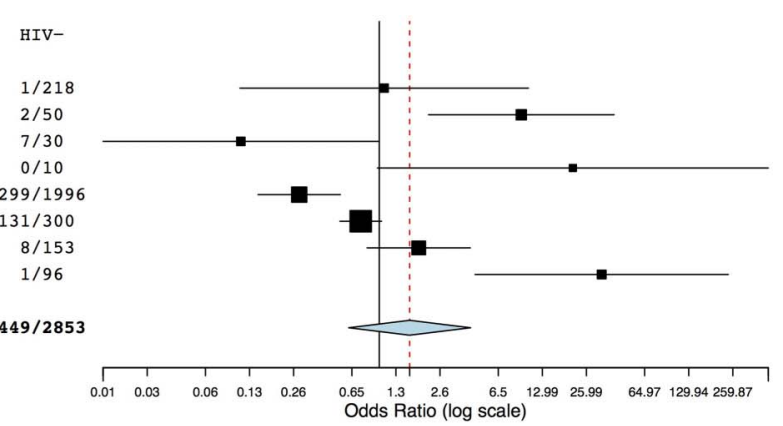

Figure 4 Meta-analysis of studies comparing T2DM in HIV-infected and HIV-uninfected participants. T2DM, type 2 diabetes mellitus.

studies examined participants on cART. Mean age ranged from 34.7 years $^{25}$ to 62 years $^{27}$ in uninfected participants and 37 years $^{30}$ to 47 years ${ }^{27}$ in infected participants. Age was significantly different between the case and control groups in three studies. ${ }^{26-28}$ Mean BMI ranged from $20.6 \mathrm{~kg} / \mathrm{m} 2^{25}$ to $28.1 \mathrm{~kg} / \mathrm{m}^{31}$ in uninfected participants and from $21.1 \mathrm{~kg} / \mathrm{m} 2^{25}$ to $25.1 \mathrm{~kg} / \mathrm{m} 2^{31}$ in infected participants. BMI was significantly different between case and control groups in three studies. ${ }^{26} 2731$ A meta-analysis using a random effects model $\left(I^{2}=84.79 \%\right)$ indicated no significant association between HIV infection and T2DM prevalence $(\mathrm{RR}=1.61,95 \% \mathrm{CI} 0.62$ to $4.21, \mathrm{p}=0.33)$, figure 4 .

\section{Prevalence of T2DM in HIV-infected treated compared with untreated participants}

Table 4 shows the data for five studies included in the meta-analysis comparing HIV treated $(n=1120)$ with untreated participants $(\mathrm{n}=828)$. The majority of included participants were women (ranged from $58 \%^{34}$ to $75 \%$ women ${ }^{36}$ ), and mean age ranged from 32.7 years $^{33}$ to 44.2 years $^{36}$ (age was not stated for Manuthu et $a \mathrm{l}^{\mathrm{B}}$ ). All treated participants were receiving cART (therapy not stated by Kagaruki et $a l^{32}$ ). Where stated, age was higher in treated compared with untreated participants, ${ }^{32} 3336$ yet significance was not stated for these age differences. Mean BMI was only reported in two studies, and was in the WHO healthy weight category $\left(22 \mathrm{~kg} / \mathrm{m}^{2}\right)$ for both groups in one study, ${ }^{33}$ and in the WHO overweight category (26.5 kg/ $\mathrm{m}^{2}$ ) for both groups in the second study. ${ }^{36} \mathrm{~A}$ meta-analysis using a random effects model $\left(\mathrm{I}^{2}=53.25 \%\right)$ indicated no significant association between HIV treatment and T2DM prevalence ( $\mathrm{RR}=1.38,95 \%$ CI 0.66 to $2.87, \mathrm{p}=0.39$ ), figure 5 .

\section{DISCUSSION}

This systematic review and meta-analysis of African studies showed no statistically significant association between HIV infection or cART exposure, and T2DM prevalence. This is in contrary to study findings of international studies in Europe and North America that have shown a higher prevalence of T2DM in HIV-infected compared with uninfected participants, ${ }^{37}$ particularly when treated with cART. ${ }^{135}$

Incidence rates of T2DM in patients with HIV were described per 1000 person years of follow-up and ranged considerably among the included studies. Cumulative incidence rate for the included studies was 17.4. For comparison, the incidence rate of T2DM in a healthy American population in 2012 was lower at $7.8 .^{38}$ Individually, three included papers reported lower incidence rates than the American population, and four reported higher incidence rates. There were no obvious differences between these studies in terms of age, sex and duration of follow-up, BMI or treatment; yet studies with larger sample sizes seemed to show higher incidence rates. A systematic review of T2DM in Sub-Saharan Africa ${ }^{4}$ found only one study reporting an incidence rate of 29 in healthy adults ( $>40$ years) in Kinshasa. ${ }^{39}$ In the present systematic review, only one included study on HIV-infected participants reported higher incidence rates than the healthy adults in Kinshasa. ${ }^{20}$ Therefore, from the limited data available and from the included studies in this systematic review, it does not seem that incidence is higher in populations infected with HIV in Africa than in a healthy ageing African population.

T2DM incidence and prevalence rates have been reported internationally in patients with HIV infection and treated patients. De Wit $e t a t^{40}$ reported T2DM incidence rates of 6 (and an incidence rate of 4 for definite cases of T2DM) from the Data Collection on Adverse Events of Anti-HIV Drugs (D:A:D) study. They examined 33389 patients with HIV infection from 212 clinics in Europe, USA, Argentina and Australia, and found that treatment with stavudine increased the RR of T2DM by 1.19 per year of exposure (conversely, treatment with ritonavir and nevirapine decreased risk of T2DM). Interestingly, controlling for lipodystrophy did not modify this relationship and a direct effect of treatment on mitochondrial toxicity was thus suggested. Baseline prevalence of T2DM in this study was $2.9 \%$. Findings from the Multicentre AIDS Cohort Study (MACS) showed a T2DM incidence of 47 in HIV-infected white males who were on cART versus 17 in those who were cART naïve; however, this study used only a single 
Table 4 Prevalence data: HIV-infected treated versus untreated

\begin{tabular}{|c|c|c|c|c|c|c|c|c|c|}
\hline Author, year & Setting & Population & $\begin{array}{l}\text { Case } \\
\text { treated }\end{array}$ & $\begin{array}{l}\text { Control } \\
\text { untreated }\end{array}$ & ART & Diagnosis & $\begin{array}{l}\text { Prevalence } \\
\text { case } \%\end{array}$ & $\begin{array}{l}\text { Prevalence } \\
\text { control \% }\end{array}$ & p Value \\
\hline $\begin{array}{l}\text { Kagaruki, } \\
2014\end{array}$ & Tanzania & $\begin{array}{l}671 \\
\text { participants, } \\
70.5 \% \text { women } \\
\text { Mean } \\
\text { age }=38.7\end{array}$ & $\begin{array}{l}\mathrm{n}=354 \\
67.8 \% \\
\text { women } \\
\text { Mean } \\
\text { age }=40.6\end{array}$ & $\begin{array}{l}\mathrm{n}=317 \\
73.5 \% \\
\text { women } \\
\text { Mean } \\
\text { age }=36.7\end{array}$ & Not stated & WHO criteria & 3.7 & 4.7 & Not stated \\
\hline $\begin{array}{l}\text { Manuthu, } \\
2008\end{array}$ & Kenya & $\begin{array}{l}295 \\
\text { participants, } \\
58 \% \text { women }\end{array}$ & $n=134$ & $n=161$ & $\begin{array}{l}\text { 82.7\% on d4t-based regimen, } 51.1 \% \\
\text { on d4T+3TC+ nevirapine } 31.6 \% \text { on } \\
\text { d4T+3TC+ efavirenz. } 17.3 \% \text { on } \\
\text { AZT-based regimens } 13.5 \% \text { on AZT } \\
+3 T C+\text { efavirenz } 3.8 \% \text { on AZT+3TC+ } \\
\text { nevirapine; one PI-based regimen } \\
\text { was AZT+3TC+ lopinavir. }\end{array}$ & $\begin{array}{l}\text { OGTT, } \\
\text { criteria not } \\
\text { stated }\end{array}$ & 1.5 & 1.2 & 0.85 \\
\hline $\begin{array}{l}\text { Mohammed, } \\
2015\end{array}$ & Ethiopia & $\begin{array}{l}393 \text { adults, } \\
66.9 \% \text { women } \\
\text { Mean } \\
\text { age }=37.9\end{array}$ & $n=284$ & $n=109$ & $\begin{array}{l}32.1 \% \text { used the drug combination } \\
\text { zidovudine + lamivudine + nevirapine }\end{array}$ & WHO criteria & 8.5 & 0.9 & $<0.01$ \\
\hline $\begin{array}{l}\text { Nsagha, } \\
2015\end{array}$ & Cameroon & $\begin{array}{l}215 \\
\text { participants, } \\
74.9 \% \text { women } \\
\text { Mean age } 44.2 \\
\text { years } \\
\text { Mean } \\
\text { BMl }=26.47\end{array}$ & $\begin{array}{l}\mathrm{n}=160 \\
77.5 \% \\
\text { women } \\
\text { Mean } \\
\text { age }=44.7 \\
\text { Mean } \\
\text { BMl }=26.94\end{array}$ & $\begin{array}{l}\mathrm{n}=55 \\
67.3 \% \\
\text { women } \\
\text { Mean } \\
\text { age }=38.6 \\
\text { Mean } \\
\text { BMl }=25.09\end{array}$ & $\begin{array}{l}\text { AZT+3TC+ efavirenx }=1.3 \%, \text { AZT } \\
+3 T C+\text { nevirapine }=50 \%, \text { TDF+3TC+ } \\
\text { efavirenz }=27.5 \%, \text { TDF+3TC+ } \\
\text { nevirapine }=13.1 \%, \text { TDF+3TC+ } \\
\text { lopinavir }=8.1 \%\end{array}$ & WHO criteria & 1.9 & 3.6 & 0.46 \\
\hline $\begin{array}{l}\text { Tesfaye, } \\
2014\end{array}$ & Ethiopia & $\begin{array}{l}374 \\
\text { participants, } \\
68 \% \text { women } \\
\text { Mean } \\
\text { age }=32.7\end{array}$ & $\begin{array}{l}\mathrm{n}=188 \\
63.8 \% \\
\text { women } \\
\text { Mean } \\
\text { age }=32.7 \\
\text { Mean } \\
\text { BMI=22.1 }\end{array}$ & $\begin{array}{l}\mathrm{n}=186 \\
68.8 \% \\
\text { women } \\
\text { Mean } \\
\text { age=32.6 } \\
\text { Mean } \\
\text { BMl=22.2 }\end{array}$ & $\begin{array}{l}58 \% \text { on regimen containing efavirenz } \\
\text { and } 42 \% \text { on nevirapine as NNRTI }\end{array}$ & IDF criteria & 33.5 & 21.5 & $<0.05$ \\
\hline
\end{tabular}

3TC, lamivudine; ART, antiretroviral therapy; AZT, zidovudine; BMI, body mass index; d4t, stavudine, IDF, International Diabetes Federation; NNRTI, non-nucleotide reverse transcriptase; OGTT, oral glucose tolerance test; PI, protease inhibitor; TDF, tenofovir. 


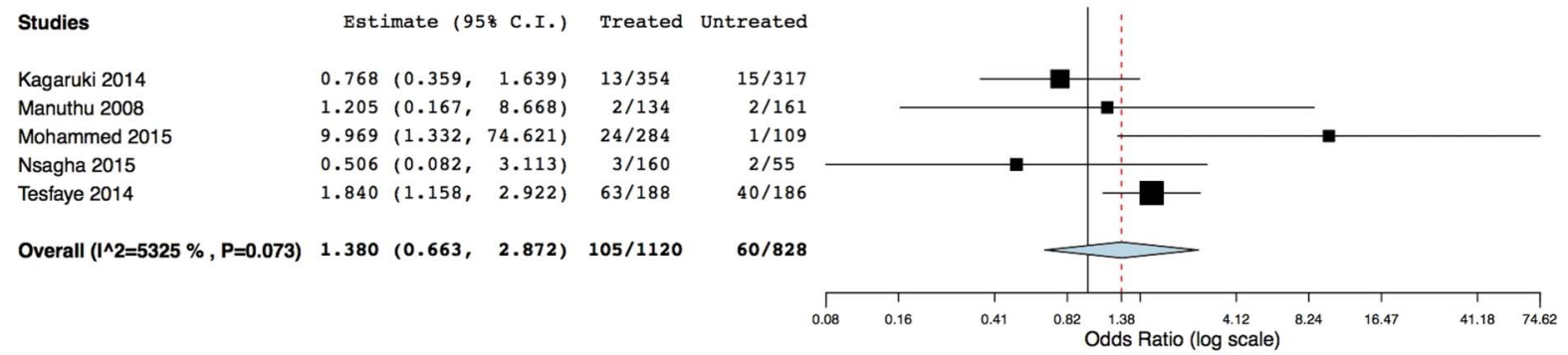

Figure 5 Meta-analysis of studies comparing T2DM in HIV-infected treated and untreated participants. T2DM, type 2 diabetes mellitus.

increased fasting plasma glucose as their diagnostic criteria. ${ }^{41}$ Nigatu et $a l^{42}$ in 2013 conducted a systematic review looking at incidence of various comorbidities, including T2DM, with HIV infection, and found a combined T2DM incidence rate of 6 (with a range of 4.236) in a sample of 44484 individuals. In the studies included in their systematic review, ART exposure increased incidence rates when compared with ART-naive patients. Conversely, Tripathi $e t a l^{8}$ found that 6816 patients with HIV infection (of which over $80 \%$ were treated with ART) had lower T2DM incidence rates than matched, non-infected individuals (11.4 vs 13.6). Similarly, Nix et at in 2014 stated that their summary of the literature found a similar decreased incidence of T2DM in HIV-infected individuals compared with controls. The present systematic review found a combined T2DM incidence rate of 17.4 in African patients with HIV infection who were cART treated, which is higher than incidence rates found in all of the abovementioned studies except for the males in the MACS study. Therefore, although incidence does not seem to be higher in patients with HIV infection in Africa compared with a normal ageing population in Africa; T2DM incidence in HIV-infected people in Africa does appear to be higher than rates reported internationally for patients with HIV infection, and those reported for a healthy American population.

It is possible that the higher incidence of T2DM in African HIV-infected individuals compared with international incidence data for HIV-infected individuals could be explained by the high presence of risk factors for T2DM in African populations, regardless of HIV status. Although prevalence of T2DM in Africa is lower than other regions in the world, the IDF Diabetes Atlas (7th edition) states that more than two-thirds of people with diabetes in Africa are undiagnosed, and that prevalence rates are expected to more than double in the next few years. This predicted increase is the highest of all regions worldwide, indicating the greatest increase in incidence rates. Furthermore, the IDF states that lack of prevalence data in Africa makes these estimates somewhat weak, and it is thus possible that prevalence in Africa is in fact higher than reported. As many African populations are undergoing rapid transitions, the toxic combination of early life undernutrition in utero and infancy, combined with excessive weight gain in later life may be contributing to increased T2DM susceptibility. ${ }^{43}$ In fact, in studies included in this systematic review where mean BMI was reported, a substantial proportion of participants infected with HIV were overweight or obese. This presents a different picture to the undernourished HIV-infected individual previously associated with Africa, and may explain a higher incidence of T2DM as an effect of lifestyle rather than an HIV disease-related risk. Although this systematic review has not shown a higher prevalence of T2DM in HIV-infected individuals compared with uninfected individuals, it does support the importance of screening for T2DM in African populations infected with HIV where T2DM incidence appears to be high. Furthermore, these findings reinforce the importance of managing and screening for metabolic disease, such as T2DM as part of routine clinical care of patients infected with HIV in order to support continuity of care. ${ }^{44}$

It is important to note that since none of the included studies were randomised, and there were too few studies for subgroup analyses, we cannot account for differences in disease course or lifestyle factors that confound exposure to cART or T2DM risk. Similarly, differences in cART exposure may be associated with regression or cure of illnesses in HIV, or with increased risk factors for T2DM. The mean age of included participants was generally $<45$ years, which may have influenced the cumulative incidence reported in this review, since age influences diabetic progression. There was also heterogeneity in the method of diagnosis of T2DM between studies, which could have confounded results. Although all of the diagnosis methods included in this systematic review were well recognised (see table 4), future T2DM screening programmes should strive to use gold standard diagnosis methods such as OGTT or HbAlc values. ${ }^{14}$ The findings of this systematic review are further limited by the high risk of bias of included studies, largely due to confounding factors and limited blinding. Furthermore, the small sample size of included studies as well as small number of studies available limit the conclusions that can be drawn. These limitations highlight the need for larger studies to be conducted examining T2DM incidence and prevalence in people with HIV in Africa, with focus on careful blinding and consideration of confounders. 
In conclusion, this meta-analysis shows no significant association between HIV infection or treatment and T2DM prevalence in African population studies. Furthermore, incidence of T2DM in Africa in patients with HIV infection on cART is no greater than in a normal ageing population, yet is higher than incidence rates in HIV-infected individuals outside of Africa. Larger case-control studies with effective blinding and consideration of confounders need to be conducted in Africa in order to further elucidate these associations in comparison with international findings. Currently, HIV infection and cART do not seem to predispose patients in Africa to T2DM; however, high incidence rates warrant focus on screening and preventative programmes for HIV-infected people living in Africa.

\section{Author affiliations}

${ }^{1}$ MRC/Wits Developmental Pathways for Health Research Unit, Faculty of Health Sciences, University of the Witwatersrand, Johannesburg, South Africa ${ }^{2}$ Julius Global Health, Julius Center for Health Sciences and Primary Care, University Medical Center Utrecht, Utrecht, The Netherlands ${ }^{3}$ Department of Pathology, Microbiology and Immunology, Vanderbilt University Medical Center, Nashville, Tennessee, USA

${ }^{4}$ Division of Infectious Disease, Department of Medicine, Vanderbilt University Medical Center, Nashville, Tennessee, USA

\section{Twitter Follow Richard Munthali @https://twitter.com/RichardMunthali}

Acknowledgements The support of the DST-NRF Centre of Excellence $(\mathrm{CoE})$ in Human Development at the University of the Witwatersrand, Johannesburg, in the Republic of South Africa is acknowledged by AP (P2015004). The work of AP was also supported by the Claude Leon Foundation.

Contributors AP contributed to conception and design; acquired, analysed and interpreted the data; drafted the article and approved the final version for publication. RJM acquired the data, revised the article and approved the final version for publication. LS, JAG, LKM and DMA acquired the data, revised the article and approved the final version for publication. SAN contributed to conception and design, acquired and interpreted the data, revised the article and approved the final version for publication. We have read and understood the BMJ policy on declaration of interests and declare that we have no competing interests.

Funding The work of DMA was supported by Vanderbilt Diabetes Research and Training Center funded by grant P30DK020593 from the National Institute of Diabetes and Digestive and Kidney Disease.

Disclaimer Opinions expressed and conclusions arrived at, are those of the author and are not to be attributed to the CoE in Human Development.

Competing interests None declared.

Provenance and peer review Not commissioned; externally peer reviewed.

Data sharing statement No additional data available.

Open Access This is an Open Access article distributed in accordance with the Creative Commons Attribution Non Commercial (CC BY-NC 4.0) license, which permits others to distribute, remix, adapt, build upon this work noncommercially, and license their derivative works on different terms, provided the original work is properly cited and the use is non-commercial. See: http:// creativecommons.org/licenses/by-nc/4.0/

\section{REFERENCES}

1. Hadigan $\mathrm{C}$, Kattakuzhy S. Diabetes mellitus type 2 and abnormal glucose metabolism in the setting of human immunodeficiency virus. Endocrinol Metab Clin North Am 2014;43:685-96.

2. Spollet G. Hyperglycemia in HIV/AIDS. Diabetes Spectrum 2006;19:163-6.
3. Samaras K. The burden of diabetes and hyperlipidemia in treated HIV infection and approaches for cardiometabolic care. Curr HIV/ AIDS Rep 2012;9:206-17.

4. Hall V, Thomsen RW, Henriksen O, et al. Diabetes in Sub Saharan Africa 1999-2011: epidemiology and public health implications. A systematic review. BMC Public Health 2011;11:564.

5. Paik IJ, Kotler DP. The prevalence and pathogenesis of diabetes mellitus in treated HIV-infection. Best Pract Res Clin Endocrinol Metab 2011;25:469-78.

6. Brown TT, Tassiopoulos K, Bosch RJ, et al. Association between systemic inflammation and incident diabetes in HIV-infected patients after initiation of antiretroviral therapy. Diabetes Care 2010;33:2244-9.

7. Ghislain M, Bastard JP, Meyer L, et al. Late antiretroviral therapy (ART) initiation is associated with long-term persistence of systemic inflammation and metabolic abnormalities. PLOS ONE 2015;10: e0144317.

8. Tripathi A, Liese AD, Jerrell JM, et al. Incidence of diabetes mellitus in a population-based cohort of HIV-infected and non-HIV-infected persons: the impact of clinical and therapeutic factors over time. Diabet Med 2014:31:1185-93.

9. Nix LM, Tien PC. Metabolic syndrome, diabetes, and cardiovascular risk in HIV. Curr HIV/AIDS Rep 2014;11:271-8.

10. Global status report on diabetes 2012. Geneva: World Health Organization; 2012.

11. Prioreschi A, Munthali R, Soepnel L, et al. The association between HIV, HIV treatment and type 2 diabetes in Africa: a systematic review. 2015. http://www.crd.york.ac.uk/PROSPERO/myprospero. php

12. Liberati A, Altman DG, Tetzlaff $J$, et al. The PRISMA statement for reporting systematic reviews and meta-analyses of studies that evaluate healthcare interventions: explanation and elaboration. $B M J$ 2009;339:b2700.

13. Samaras K. Prevalence and pathogenesis of diabetes mellitus in HIV-1 infection treated with combined antiretroviral therapy. J Acquir Immune Defic Syndr 2009;50:499-505.

14. Sacks DB. A1C versus glucose testing: a comparison. Diabetes Care 2011;34:518-23.

15. Higgins JPT, Green S. eds. Cochrane Handbook for Systematic Reviews of Interventions 4.2.6 [updated September 2006]. In: Chichester, UK: John Wiley \& Sons, Ltd, 2006:6. The Cochrane Library

16. Busse JW GG. Tool to Assess Risk of Bias in Case-control Studies. https://distillercercom/resources/2016.

17. Abrahams Z, Dave JA, Maartens G, et al. Changes in blood pressure, glucose levels, insulin secretion and anthropometry after long term exposure to antiretroviral therapy in South African women. AIDS Res Ther 2015;12:24.

18. George JA, Venter WDF, Deventer HE, et al. A longitudinal study of the changes in body fat and metabolic parameters in a South African Population of HIV-positive patients receiving an antiretroviral therapeutic regimen containing stavudine. AIDS Res Hum Retroviruses 2009;25:771-81.

19. Karamchand S, Leisegang R, Schomaker M, et al. Risk factors for incident diabetes in a cohort taking first-line Nonnucleoside reverse transcriptase inhibitor-based antiretroviral therapy. Medicine (Baltimore) 2016;95:e2844.

20. Magula NP, Motala AA, Lalloo UG. The prevalence and incidence of diabetes mellitus and other disorders of glycaemia in South African black patients on antiretroviral therapy. Int $J$ Infect Dis 2014;21:10.

21. Mandina Ndona M, Longo-Mbenza B, Wumba R, et al. Nadir CD4+, religion, antiretroviral therapy, incidence of type 2 diabetes mellitus, and increasing rates of obesity among black Africans with HIV disease. Int J Gen Med 2012;5:983-90.

22. Sagna $\mathrm{Y}$, Tiéno $\mathrm{H}$, Guira $\mathrm{O}$, et al. Following of newly managed adult HIV infected patients in the National Referral Centre, Burkina Faso: three years outcomes study. Sex Transm Infect 2013;89:A1-A428.

23. Zannou DM, Denoeud L, Lacombe K, et al. Original article Incidence of lipodystrophy and metabolic disorders in patients starting non-nucleoside reverse transcriptase inhibitors in Benin. Antivir Ther (Lond) 2009;14:371-80.

24. Amusa GA, Awokola BI, Akanbi MO, et al. Burden of cardiovascular disease risk factors in HIV-infected adults in North-Central Nigeria. Am J Respir Crit Care Med 2015;191:A4521.

25. Anastos K, Ndamage F, Lu D, et al. Lipoprotein levels and cardiovascular risk in HIV-infected and uninfected Rwandan women. AIDS Res Ther 2010;7:2-7.

26. Becker AC, Sliwa K, Stewart S, et al. Acute coronary syndromes in treatment-naive black South Africans with human immunodeficiency virus infection. J Interv Cardiol 2010;23:70-7. 
27. Brand M, Woodiwiss AJ, Michel F, et al. Large vessel adventitial vasculitis characterizes patients with critical lower limb ischemia with as compared to without human immunodeficiency virus infection. PLOS ONE 2014;9:e106205.

28. Edwards JK, Bygrave $\mathrm{H}$, Van den Bergh R, et al. HIV with non-communicable diseases in primary care in Kibera, Nairobi, Kenya: characteristics and outcomes 2010-2013. Trans R Soc Trop Med Hyg 2015;109:440-6.

29. Fourie CM, Van Rooyen JM, Kruger A, et al. Lipid abnormalities in a never-treated HIV-1 subtype C-infected African population. Lipids 2010;45:73-80.

30. Maganga E, Smart LR, Kalluvya S, et al. Glucose metabolism disorders, HIV and antiretroviral therapy among Tanzanian adults. PLOS ONE 2015;10:e0134410.

31. Ngatchou W, Lemogoum D, Ndobo P, et al. Increased burden and severity of metabolic syndrome and arterial stiffness in treatment-naive HIV+ patients from Cameroon. Vasc Health Risk Manag 2013;9:509-16.

32. Kagaruki GB, Mayige MT, Ngadaya ES, et al. Magnitude and risk factors of non-communicable diseases among people living with HIV in Tanzania : a cross sectional study from Mbeya and Dar es Salaam regions. BMC Public Health 2014;14:1-9.

33. Tesfaye DY, Kinde S, Medhin G, et al. Burden of metabolic syndrome among HIV-infected patients in Southern Ethiopia. Diabetes Metab Syndr 2014;8:102-7.

34. Manuthu EM, Joshi MD, Lule GN, et al. Prevalence of dyslipidemia and dysglycaemia in HIV infected patients. East Afr Med J 2008;85:10-17.

35. Mohammed AE, Shenkute TY, Gebisa WC. Diabetes mellitus and risk factors in human immunodeficiency virus-infected individuals at Jimma University Specialized Hospital, Southwest Ethiopia. Diabetes Metab Syndr Obes 2015;8:197-206.
36. Nsagha DS, Clement J, Assob N, et al. Risk factors of cardiovascular diseases in HIV/AIDS patients on HAART. The Open AIDS Journla 2015;9:51-9.

37. Galli L, Salpietro S, Pellicciotta G, et al. Risk of type 2 diabetes among HIV-infected and healthy subjects in Italy. Eur J Epidemiol 2012;27:657-65.

38. National Diabetes Statistics Report: Estimates of Diabetes and Its Burden in the United States, 2014. Centers for Disease Control and Prevention. In: Atlanta, GA: U.S. Department of Health and Human Services, 2014.

39. Longo-Mbenza B, On'kin JB, Okwe AN, et al. Metabolic syndrome, aging, physical inactivity, and incidence of type 2 diabetes in general African population. Diab Vasc Dis Res 2010;7:28-39.

40. De Wit S, Sabin CA, Weber R, et al. Incidence and risk factors for new-onset diabetes in HIV-infected patients: the Data Collection on Adverse Events of Anti-HIV Drugs (D:A:D) study. Diabetes Care 2008;31:1224-9.

41. Brown TT CS, Li X, Kingsley LA, et al. Antiretroviral therapy and the prevalence and incidence of diabetes mellitus in the multicenter AIDS cohort study. Arch Intern Med 2005;165: 1179-84.

42. Nigatu T, Oldenburg B, Elliott J, et al. The incidence of cardiovascular disease, cancer and type 2 diabetes comorbidities in HIV infection: a systematic review. J Nurs EducPract 2013;3: 58-67.

43. Victora CG AL, Fall C, Hallal PC, et al. Maternal and child undernutrition: consequences for adult health and human capital. Lancet 2008;2008:340-57.

44. Rabkin M, Melaku Z, Bruce K, et al. Strengthening health systems for chronic care: leveraging HIV programs to support diabetes services in Ethiopia and Swaziland. J Trop Med 2012;2012: 137460 . 